Mеталлофиз. новейшие технол. / Metallofiz. Noveishie Tekhnol. @ 2018 ИМФ (Институт металлофизики 2018, т. 40, № 5, сc. 637-648 / DOI: 10.15407/mfint.40.05.0637 им. Г. В. Курдюмова НАН Украины) Оттиски доступны непосредственно от издателя

Фотокопирование разрешено только

Напечатано в Украине.

в соответствии с лицензией

PACS numbers: 61.05.cp, 81.05.Je, 81.07.Bc, 81.07.De, 81.07.Wx, 81.20.Ev

\title{
Synthesis of the WC and $\mathrm{Mo}_{2} \mathrm{C}$ Carbides by Mechanical Alloying of Metal Powder and Carbon Nanotubes
}

\author{
O. Nakonechna, M. Dashevskyi, and N. Belyavina
}

Taras Shevchenko National University of Kyiv, Faculty of Physics, 60 Volodymyrska Str., UA-01033 Kyiv, Ukraine

Nanoscale WC and $\mathrm{Mo}_{2} \mathrm{C}$ carbides are synthesized from the elemental metal powder (with particle size of about $40 \mu \mathrm{m}$; purity is not less than $99.6 \%$ wt.) and the carbon nanotubes (CNTs, with average diameter of 10-20 nm) by mechanical alloying in a high-energy planetary ball mill for the first time. Nature of interaction of the charge components at processing in a ball mill is studied on test samples (selected at each 1-2 hours of synthesis) using a complex of x-ray techniques. These techniques include: a full-profile analysis for the primary processing of diffractograms obtained with DRON-3M apparatus; qualitative and quantitative phase analysis for determining the phase composition of the products of synthesis; x-ray structural analysis to verify and refine the structural models; Williamson-Hall method for determining the grain sizes of synthesized carbides and microdistortions of their crystal lattice. Four hours of charge processing result in a formation of the hightemperature $\mathrm{W}_{2} \mathrm{C}$ and $\mathrm{Mo}_{2} \mathrm{C}$ carbides, the crystal structure of which is related to the $\zeta-\mathrm{Fe}_{2} \mathrm{~N}$ structure type with vacancies within the metal sublattice. Further milling of W-CNT mixture (up to 10 hours) is accompanied by the $\mathrm{W}_{2} \mathrm{C}+\mathrm{CNT} \rightarrow$ WC transformation, while processing of the Mo-CNT mixture leads to its dispersion. The effect of CNTs on mechanochemical synthesis of the WC and $\mathrm{Mo}_{2} \mathrm{C}$ carbides is considered. As shown, the mechanical alloying of $\mathrm{W} / \mathrm{Mo}-\mathrm{CNT}$ is a highly effective method for the fabrication of the WC and $\mathrm{Mo}_{2} \mathrm{C}$ carbides. Due to their unique mechanical characteristics (high hardness, wear resistance, and strength), these materials are widely used in mak-

Corresponding author: Olesya Ivanivna Nakonechna

E-mail: les@univ.kiev.ua

Citation: O. Nakonechna, M. Dashevskyi, and N. Belyavina, Synthesis of the WC and $\mathrm{Mo}_{2} \mathrm{C}$ Carbides by Mechanical Alloying of Metal Powder and Carbon Nanotubes, Metallofiz. Noveishie Tekhnol., 40, No. 5: 637-647 (2018), DOI: $10.15407 /$ mfint.40.05.0637. 
ing materials for the abrasive and metal cutting tools.

Key words: carbon nanotube, nanocomposite, mechanical alloying, x-ray diffraction.

Механохемічною методою у високоенергетичному планетарному кульовому млині з порошків металів (розмір частинок - близько 40 мкм, чистота не нижче 99,6\% мас.) і вуглецевих нанотрубок (ВНТ, середній діяметер - 10-20 нм) вперше синтезовано нанорозмірні карбіди WC та $\mathrm{Mo}_{2} \mathrm{C}$. Дослідження характеру взаємодії компонентів шихти в процесі її оброблення в млині проведено на тестових зразках (відбір продуктів синтези через кожні 1-2 години) з використанням комплексу рентгенівських методик, а саме: повнопрофільної аналізи для первинного оброблення дифрактограм, одержаних на апараті ДРОН-3М; якісної та кількісної фазової аналізи для визначення фазового складу продуктів синтези; рентгеноструктурної аналізи для перевірки й уточнення структурних моделів; методики Вільямсона-Голла для визначення розмірів зерен синтезованих карбідів і мікроспотворень їхньої кристалічної гратниці. В результаті показано, що вже після чотирьох годин оброблення шихти продуктами синтези є високотемпературні карбіди $\mathrm{W}_{2} \mathrm{C}$ i $\mathrm{Mo}_{2} \mathrm{C}$, кристалічна структура яких належить до структурного типу $\zeta-\mathrm{Fe}_{2} \mathrm{~N}$ із вакансіями в підгратниці металу. Подальше розмелювання суміші W-BHT (до 10 годин) супроводжується перетворенням $\mathrm{W}_{2} \mathrm{C}+\mathrm{BHT} \rightarrow \mathrm{WC}$, а розмелювання суміші Мо-ВНT приводить до їі диспергування. Середній розмір зерна WC на кінцевій стадії оброблення складає $\approx 4 \mathrm{Hм}$, а $\mathrm{Mo}_{2} \mathrm{C}-$ близько $12 \mathrm{Hм}$, що свідчить про нанорозмірність синтезованих карбідів. Розглянуто вплив ВНТ на характер взаємодії компонентів шихти та показано, що механохемічна синтеза W/Mo-ВНТ є високоефективною методою одержання карбідів $\mathrm{WC}$ i $\mathrm{Mo}_{2} \mathrm{C}$, які завдяки їх унікальним механічним характеристикам (високій твердості, зносостійкості та міцності) є основними легувальними компонентами металевих стопів, що широко використовуються в металообробленні та інших галузях промисловости.

Ключові слова: вуглецева нанотрубка, нанокомпозит, механохемічна синтеза, рентгенівська дифракція.

Механохимическим методом в высокоэнергетической планетарной шаровой мельнице из порошков металлов (размер частиц - около 40 мкм, чистота не ниже $99,6 \%$ вес.) и углеродных нанотрубок (УНТ, средний диаметр - 10-20 нм) впервые синтезированы наноразмерные карбиды WC и $\mathrm{Mo}_{2} \mathrm{C}$. Исследование характера взаимодействия компонентов шихты в процессе её обработки в мельнице проведено на тестовых образцах (отбор продуктов синтеза - через каждые 1-2 часа) с использованием комплекса рентгеновских методик, а именно: полнопрофильного анализа для первичной обработки дифрактограмм, полученных на аппарате ДРОН-3М; качественного и количественного фазового анализа для определения фазового состава продуктов синтеза; рентгеноструктурного анализа для проверки и уточнения структурных моделей; методики ВильямсонаХолла для определения размеров зёрен синтезированных карбидов и микроискажений их кристаллической решётки. В результате показано, что уже после четырёх часов обработки шихты продуктами синтеза явля- 
ются высокотемпературные карбиды $\mathrm{W}_{2} \mathrm{C}$ и $\mathrm{Mo}_{2} \mathrm{C}$, кристаллическая структура которых отнесена к структурному типу $\zeta-\mathrm{Fe}_{2} \mathrm{~N}$ с вакансиями в подрешётке металла. Дальнейший размол смеси W-УНТ (до 10 часов) сопровождается превращением $\mathrm{W}_{2} \mathrm{C}+\mathrm{УHT} \rightarrow \mathrm{WC}$, а размол смеси Мо-УНT приводит к её диспергированию. Средний размер зерна WC на конечной стадии обработки составляет $\approx 4$ нм, а $\mathrm{Mo}_{2} \mathrm{C}$ - около 12 нм, что свидетельствует о наноразмерности синтезированных карбидов. Рассмотрено влияние УНТ на характер взаимодействия компонентов шихты и показано, что механохимический синтез W/Mo-УНТ является высокоэффективным методом получения карбидов $\mathrm{WC}$ и $\mathrm{Mo}_{2} \mathrm{C}$, которые благодаря их уникальным механическим характеристикам (высокой твёрдости, износостойкости и прочности) являются основными легирующими компонентами металлических сплавов, широко используемых в металлообработке и других областях промышленности.

Ключевые слова: углеродная нанотрубка, нанокомпозит, механохимический синтез, рентгеновская дифракция.

(Received March 18, 2018)

\section{INTRODUCTION}

As known, the principal application for carbides is as the major constituent in 'cemented carbides' cutting tools [1]. The term 'cemented carbides' refers to IVb-VIb carbides bonded together in a metal matrix, usually cobalt. Due to its extremely hardness, high abrasion resistance, and strength, the WC monocarbide is the most important one widely used in making materials for the abrasive and metal cutting tools. Moreover, in refractory alloys, the carbides of Mo like carbides of $\mathrm{W}$ are used as a minor constituent to act as dispersion reinforces.

Some powder-metallurgy techniques are used for manufacturing the polycrystalline VIb carbides. Direct reaction of metal or metal hydride powders with carbon is often the most common laboratory method for their fabrication. Other techniques are based on a direct reaction of the metal oxides and excess carbon in a protective or reducing atmosphere; reaction of the metal with a carburizing gas as well as on precipitation from the gas phase by reacting the metal halide or metal carbonyl in hydrogen [1]. Typical reaction temperatures for these processing techniques are $1300-2300^{\circ} \mathrm{C}$.

From the above, it can be concluded that the obtaining of homogeneous metal carbides with high purity via the traditional ways of fabrication is a difficult task. This is attributed to the application of high temperatures that may restrict the fabrication process. Accordingly, the high cost of this process is considered a major disadvantage for these processes and this increases the price of the end product [2].

In our opinion, special focus should be paid on such simple and effective technique as mechanical alloying/milling of the initial charge of 
metal and carbon powders. The main advantages of this method lie on the one hand in the possibility of performing the process at room temperature in a ball mill, and on the other hand in the nanoscale products obtained $[3,4]$. Previously, the authors $[2,5,6]$ have successfully applied the direct room-temperature synthesis of WC carbide with a fine grain size of $5 \mathrm{~nm}$ [6] by mixing the correct proportions of $\mathrm{W}$ and activated carbon or graphite and milling the powder mixture for 310 hours [5] or 120 hours [6] in a planetary ball mill [6]. The milled WC powder was consolidated and the obtained product demonstrated good mechanical properties: hardness of $21 \mathrm{GPa}$, Young's modulus of $800 \mathrm{GPa}$, and shear modulus of $400 \mathrm{GPa}$. As far as we know, the direct roomtemperature synthesis of $\mathrm{Mo}_{2} \mathrm{C}$ carbide has not been carried out yet as well as there is no information about direct room-temperature synthesis of the WC or $\mathrm{Mo}_{2} \mathrm{C}$ carbides using the carbon in a form of carbon nanotubes (CNTs). However, our research [7] has revealed that the use of CNTs instead of graphite in the $\mathrm{Fe}_{3} \mathrm{C}$ carbide preparation makes the synthesis more productive since the processing time shortens.

Here, the direct mechanical alloying has been performed in order to obtain the WC and $\mathrm{Mo}_{2} \mathrm{C}$ carbides from elementary metal-CNT powder mixture using a high-energy planetary ball mill. Phase composition and structure of materials obtained have studied and analysed.

\section{EXPERIMENTAL DETAILS}

Tungsten and molybdenum powders (particle sizes of about $40 \mu \mathrm{m}$, $99.6 \%$ wt. of purity) and multiwalled CNTs were mixed together in desired proportion. Multiwalled carbon nanotubes used here were synthesized by the catalytic chemical vapour deposition method (CVD) at TM Spetzmash Ltd (Kyiv, Ukraine). Parameters of CNTs are as follow: the average diameter is of $10-20 \mathrm{~nm}$, the specific surface area (determined by argon desorption method) is of $200-400 \mathrm{~m}^{2} / \mathrm{g}$, and their poured bulk density varies from 20 to $40 \mathrm{~g} / \mathrm{dm}^{3}$.

Mechanical alloying of the charge sealed in a vial (stainless steel, $70 \mathrm{~mm}$ height, $50 \mathrm{~mm}$ diameter) under an argon atmosphere has been performed in a high-energy planetary ball mill. The hardened stainless balls were used to carry out the experiments. The rotation speed was equal to $1480 \mathrm{rpm}$; the acceleration was about $50 \mathrm{~g}$; the pressure for a substance particle reached $5 \mathrm{GPa}$. The cycled milling process $(\cong 1-2$ hours of treatment and 30 min of cooling time) was carried out under an argon atmosphere. The vial temperature was held at below $375 \mathrm{~K}$ during the experiments.

The full complex of the x-ray diffraction methods (XRD) has been used to study the phase transformation occurred during milling of the $\mathrm{Me}-\mathrm{C}$ powder mixtures. XRD data was collected for the test samples selected after a certain milling time with DRON-3M automatic diffrac- 
tometer $\left(\mathrm{Cu} K_{\alpha}\right.$ radiation). The diffraction patterns have been obtained in a discrete mode under the following scanning parameters: observation range $2 \theta=20-100^{\circ}$, step scan of $0.05^{\circ}$, and counting time per step at $3 \mathrm{~s}$.

The original software package developed by us for the automated DRON equipment and including full complex of standard Rietveld refinement procedure has been used for analysis and interpretation of the $\mathrm{X}$-ray diffraction data obtained. This package is elaborated using known algorithms [8] and intended for solving different XRD tasks, namely, determination of both peak positions and integral intensities of the Bragg's reflections by means of full profile analysis; carrying out qualitative and quantitative phase analysis using PDF data for phase identification and the least square method for lattice parameters refinement; testing of the structure models and refining crystal structure parameters (including coordinates, atomic position filling, texture, etc.). More details concerning of this package are presented in [9].

Due to the broadening of the diffraction peaks, it is possible to estimate the average grain sizes $D$ and strains $\varepsilon$ of the $\mathrm{Me}-\mathrm{C}$ carbides formed in the test samples using the classical Williamson-Hall plot [10]. In this method, the dependences of scaled broadening of reflections $b^{*}(2 \theta)$ on scattering vector $\mathbf{S}$ are analysed. The scaled broadening for each $(h k l)$ reflection could be expressed as $b^{*}(2 \theta)=(\beta(2 \theta) \cos \theta) / \lambda$, where $\theta$ is the Bragg's reflection, $\lambda$ is the $x$-ray wavelength and the physical broadening $\quad \beta(2 \theta)=\left(F W H M_{\text {exp }}^{2}-F W H M_{\mathrm{R}}^{2}\right)^{1 / 2} \quad$ (where $F W H M_{\text {exp }}$ and $F W H M_{\mathrm{R}}$ are experimental and instrumental broadening, respectively). Scattering-vector magnitude has defined as $S=(2 \sin \theta) / \lambda$ for each XRD peak.

Using the plots constructed for each $\mathrm{Me}-\mathrm{C}$ carbide, the average grain size values $D$ could be found by extrapolating the dependencies of $b^{*}(2 \theta)$ onto $S=0$ axes as $D=1 / b^{*}(2 \theta)$ and the average $\varepsilon$ values, which characterize microdeformation of crystal lattice, could be found from a slope of the $b^{*}(2 \theta)$ straight line versus $S$ as $\varepsilon=b^{*}(2 \theta) /(2 S)$.

\section{RESULTS AND DISCUSSION}

To study the process of the $\mathrm{WC}$ and $\mathrm{Mo}_{2} \mathrm{C}$ carbides formation, a set of experiments on mechanical alloying of the mixtures containing initial metal powders and CNTs multiwall nanotubes as the carbon component (Me:CNTs proportion is equal to 1:1 for $\mathrm{WC}$ and 2:1 for $\mathrm{Mo}_{2} \mathrm{C}$ ) has been performed. In order to control the phase transformations at milling of the charge, the phase composition of the test samples selected after each 1-2 hours of treatment in a ball mill have been studied. According to the XRD results, all test samples treated up to 4 hours in a ball mill contain initial metal only (or initial metal mainly) since CNTs are x-ray amorphous and do not contribute into diffraction pattern [7]. 


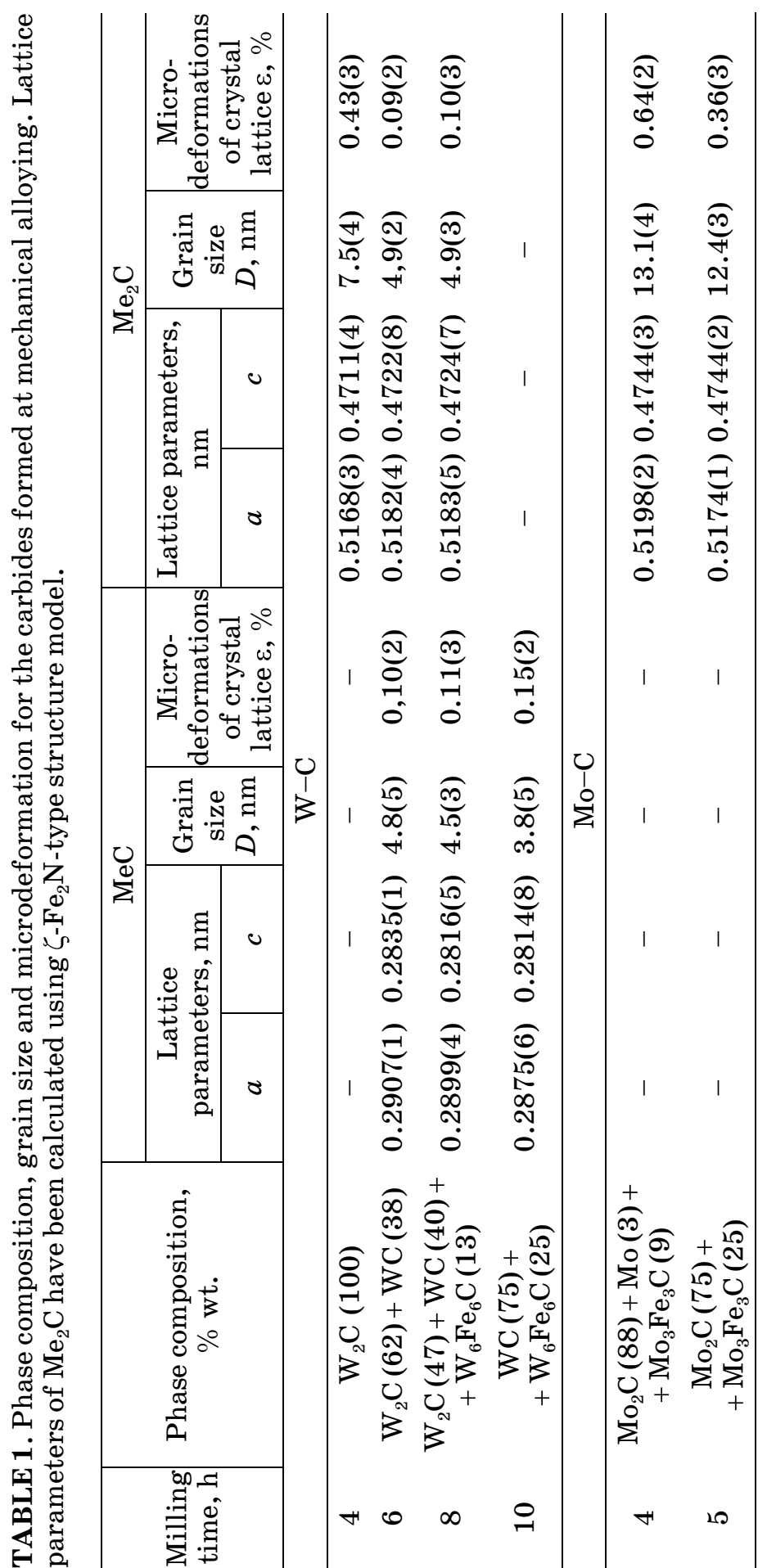


It should be noted that we took under consideration the data of Refs. $[11,12]$ on the compounds existing in the $\mathrm{W}-\mathrm{C}$ and Mo-C phase diagrams when analyse the XRD data obtained.

Synthesis of WC carbide. The $\mathrm{W}_{2} \mathrm{C}$ carbide is the main constituent of the test sample after 4 hours of milling (Table 1, Fig. 1). According to Ref. [13], three polymorphous modifications are inherent to this carbide, namely, low-temperature $\left(1250-2100^{\circ} \mathrm{C}\right) \mathrm{W}_{2} \mathrm{C}$ with own type structure, high-temperature $\left(2100-2400^{\circ} \mathrm{C}\right) \mathrm{W}_{2} \mathrm{C}$ with $\mathrm{Mo}_{2} \mathrm{C}$-type structure (distorted $\zeta-\mathrm{Fe}_{2} \mathrm{~N}$-type structure) and high-temperature $\left(2400-2780^{\circ} \mathrm{C}\right) \mathrm{W}_{2} \mathrm{C}$ with $\zeta-\mathrm{Fe}_{2} \mathrm{~N}$-type structure.

So, each of three structure types mentioned above were taken as trial models for crystal structure determination of $\mathrm{W}_{2} \mathrm{C}$ carbide formed after 4 hours of treatment in a ball mill. The first calculation has been made in a framework of the most simple $\mathrm{W}_{2} \mathrm{C}$ structure $(P-3 m 1$ space group, $a=0.2984(4) \mathrm{nm}, c=0.4710(4) \mathrm{nm})$ : W in 2(d) 0.3330 .6670 .25 and $\mathrm{C}$ in 1(a) 000 . Refining of atomic position filling, texture and isotropic temperature factors fulfilled in the framework of this type structure did not lead to a good agreement between experimental and calculated intensities of reflections at diffraction pattern (the $R_{\mathrm{B}}$ reliability factors did not exceed the value of 0.09 ), besides it has revealed an anomalous value of the calculated carbide composition (56(1) at.\% $\mathrm{W})$. Therefore, further calculations for the $\mathrm{W}_{2} \mathrm{C}$ structure have provided in the framework of the $\mathrm{Mo}_{2} \mathrm{C}$-type structure and the $\zeta-\mathrm{Fe}_{2} \mathrm{~N}$-one as well. The correctness of these calculations was controlled by the $R_{\mathrm{B}}$

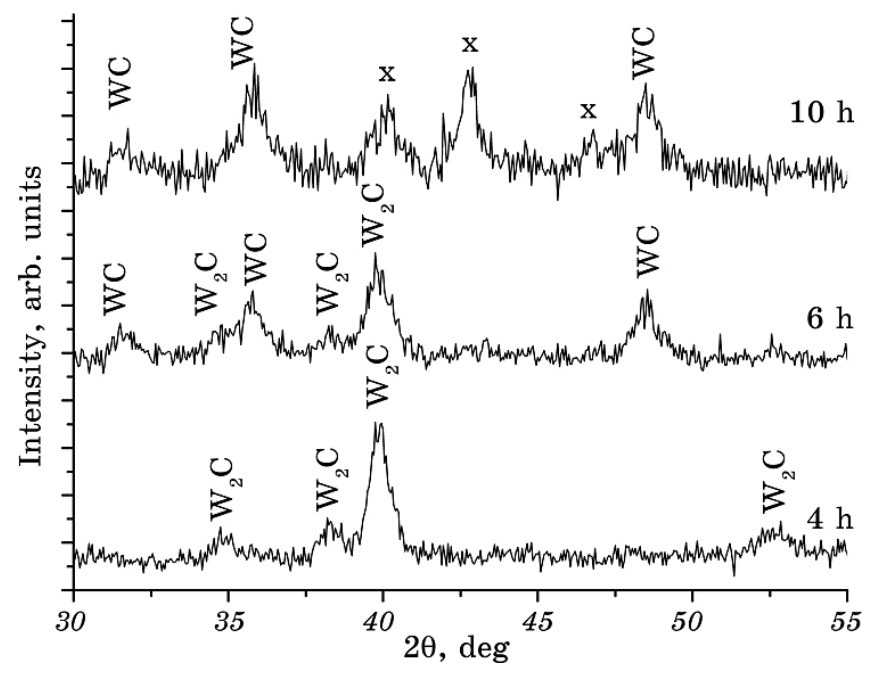

Fig. 1. Fragments of XRD patterns of the test samples obtained by mechanical alloying of the W:CNT $(1: 1)$ mixture in a ball mill (reflections of the $\mathrm{W}_{6} \mathrm{Fe}_{6} \mathrm{C}$ carbide are marked as ' $\mathrm{x}$ '); radiation $\mathrm{Cu} K_{\alpha}$. 
TABLE 2. Crystal data for the $\mathrm{W}_{2} \mathrm{C}$ and $\mathrm{Mo}_{2} \mathrm{C}$ carbides formed after 4 hours processing in a ball mill.

\begin{tabular}{|c|c|c|c|c|c|}
\hline Atom & Site & Site occ. & $x$ & $y$ & $z$ \\
\hline \multicolumn{6}{|c|}{$\mathrm{W}_{2} \mathrm{C}\left(\zeta-\mathrm{Fe}_{2} \mathrm{~N}\right.$-type structure $)$} \\
\hline $\mathrm{W}$ & $6 \mathrm{k}$ & $0.93(1)$ & $0.333(1)$ & 0 & $0.280(3)$ \\
\hline $\mathrm{C}(1)$ & $2 d$ & $1.00(1)$ & 0.333 & 0.667 & 0.5 \\
\hline $\mathrm{C}(2)$ & $1 \mathrm{a}$ & $1.00(1)$ & 0 & 0 & 0 \\
\hline \multicolumn{3}{|c|}{ Space group } & \multicolumn{3}{|c|}{$P-31 m$ (No. 162) } \\
\hline \multicolumn{3}{|c|}{ Lattice parameter, $\mathrm{nm}$} & \multicolumn{3}{|c|}{$a=0.5168(3), c=0.4710(4)$} \\
\hline \multicolumn{3}{|c|}{ Independent reflections } & \multicolumn{3}{|c|}{27} \\
\hline \multicolumn{3}{|c|}{ Total isotropic $B$ factor, $\mathrm{nm}^{2}$} & \multicolumn{3}{|c|}{$B=1.80(2) \cdot 10^{-2}$} \\
\hline \multicolumn{3}{|c|}{ Calculated content, at. $\%$} & \multicolumn{3}{|c|}{$65.1(3) \mathrm{W}+34.9(3) \mathrm{C}$} \\
\hline \multicolumn{3}{|c|}{ Reliability factor } & \multicolumn{3}{|c|}{$R_{\mathrm{B}}=0.049$} \\
\hline \multicolumn{6}{|c|}{$\mathrm{Mo}_{2} \mathrm{C}\left(\zeta-\mathrm{Fe}_{2} \mathrm{~N}\right.$-type structure $)$} \\
\hline Mo & $6 \mathrm{k}$ & $0.80(2)$ & $0.333(1)$ & 0 & $0.250(3)$ \\
\hline $\mathrm{C}(1)$ & $2 d$ & $1.00(1)$ & 0.333 & 0.667 & 0.5 \\
\hline $\mathrm{C}(2)$ & $1 \mathrm{a}$ & $1.00(1)$ & 0 & 0 & 0 \\
\hline \multicolumn{3}{|c|}{ Space group } & \multicolumn{3}{|c|}{$P-31 m$ (No. 162) } \\
\hline \multicolumn{3}{|c|}{ Lattice parameter, $\mathrm{nm}$} & \multicolumn{3}{|c|}{$a=0.5174(3), c=0.4744(4)$} \\
\hline \multicolumn{3}{|c|}{ Independent reflections } & \multicolumn{3}{|c|}{16} \\
\hline \multicolumn{3}{|c|}{ Total isotropic $B$ factor, $\mathrm{nm}^{2}$} & \multicolumn{3}{|c|}{$B=1.92(6) \cdot 10^{-2}$} \\
\hline \multicolumn{3}{|c|}{ Calculated content, at. $\%$} & \multicolumn{3}{|c|}{ 61.7(3) Mo $+38.3(3) \mathrm{C}$} \\
\hline \multicolumn{3}{|c|}{ Reliability factor } & \multicolumn{3}{|c|}{$R_{\mathrm{B}}=0.056$} \\
\hline
\end{tabular}

reliability factors, which did not exceed the value of 0.05 for each model. That is why a more symmetrical model ( $\zeta-\mathrm{Fe}_{2} \mathrm{~N}$-type structure) was chosen for the $\mathrm{W}_{2} \mathrm{C}$ carbide structure (Table 2). As a result, calculation has revealed that the vacancies exist in $6(\mathrm{k})$ position filled with the tungsten atoms. Presence of vacancies in a metal sublattice leads to shift of the $\mathrm{W}_{2} \mathrm{C}$ composition onto $\cong 35$ at. $\% \mathrm{C}$ (Table 2 ), which is inherent to carbon-rich side of the solid solution on the base of high temperature $\mathrm{W}_{2} \mathrm{C}$ modification [13].

Further processing (up to 10 hours) results in a gradual $\mathrm{W}_{2} \mathrm{C} \rightarrow \mathrm{WC}$ transformation (Fig. 1, Table 1). According to the phase analysis results, the formation of WC monocarbide is accompanied by the wear debris, which leads to formation of the cubic $\mathrm{W}_{6} \mathrm{Fe}_{6} \mathrm{C}$ carbide with $a=1.093(1) \mathrm{nm}$. Therefore, the final sample (10 hours of processing) contains an admixture of $\mathrm{W}_{6} \mathrm{Fe}_{6} \mathrm{C}$ phase (marked as ' $\mathrm{x}$ ' at Fig. 1) along with the WC phase. Crystal structure calculation has revealed that WC carbide crystallizes in a completely filled structure (own typestructure, space group $P-6 m 2, a=0.2874(4) \mathrm{nm}, c=0.2811(5) \mathrm{nm}): \mathrm{W}$ in 1(a) 000 , C in 1(d) $0.3330 .6670 .5\left(R_{\mathrm{B}}=0.054\right)$. 
Phase compositions of the test samples as well as the refined values of lattice parameters of the $\mathrm{W}-\mathrm{C}$ carbides formed in the milled powder are listed in Table 1.

The average grain sizes $D$ and strains $\varepsilon$ of the $\mathrm{WC}$ and $\mathrm{W}_{2} \mathrm{C}$ carbides formed in the final milling products have estimated using the classical Williamson-Hall plot. These values are summarized in Table 1 and reveal that grain sizes are equal to $4-7 \mathrm{~nm}$ for $\mathrm{W}-\mathrm{C}$ carbides synthesized here by mechanical alloying.

Therefore, results obtained have proved that mechanical alloying of an equiatomic mixture of the tungsten powder and CNTs results in a stepwise formation of the $\mathrm{W}_{2} \mathrm{C} \rightarrow \mathrm{WC}$ carbides. At the first stage, the product of such processing is the high temperature $\mathrm{W}_{2} \mathrm{C}$ carbide $(\zeta$ $\mathrm{Fe}_{2} \mathrm{~N}$-type structure), which is usually formed congruently at $2775^{\circ} \mathrm{C}$ $[11,13]$. Then, the WC monocarbide forms as a result of $\mathrm{W}_{2} \mathrm{C}+\mathrm{CNT} \rightarrow \mathrm{WC}$ transformation after 6 hours of milling, at the second stage of processing. Finally, WC monocarbide becomes the main phase constituent of the nanocomposite powder (grain size of about $4 \mathrm{~nm}$ ) obtained after 10 hours of treatment of the charge in a ball mill.

Synthesis of $\mathrm{Mo}_{2} \mathbf{C}$ carbide. According to Ref. [13], three polymorphous modifications are inherent to $\mathrm{Mo}_{2} \mathrm{C}$ carbide, namely, hightemperature $\left(1440-2522^{\circ} \mathrm{C}\right) \mathrm{Mo}_{2} \mathrm{C}$ with $\mathrm{W}_{2} \mathrm{C}$-type structure, hightemperature $\left(1200-1440^{\circ} \mathrm{C}\right) \mathrm{Mo}_{2} \mathrm{C}$ with own type structure (distorted $\zeta-\mathrm{Fe}_{2} \mathrm{~N}$-type structure $)$, and low-temperature $\left(<1200^{\circ} \mathrm{C}\right) \mathrm{Mo}_{2} \mathrm{C}$.

The diffraction patterns of the test sample processed for 4 hours and

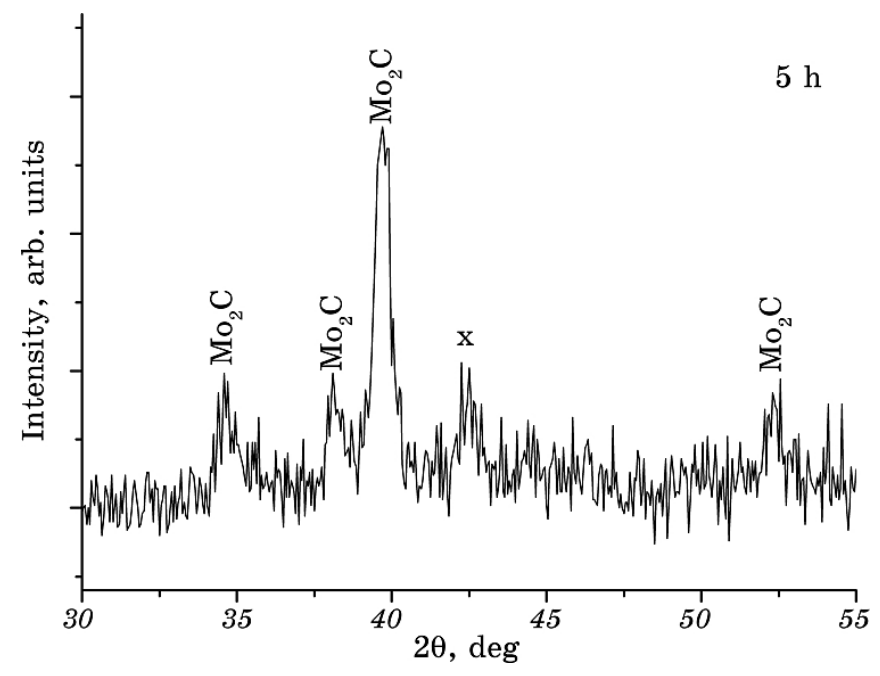

Fig. 2. Fragment of XRD pattern of the test samples obtained by mechanical alloying of the Mo:CNTs (2:1) mixture in a ball mill (reflections of the $\mathrm{Mo}_{3} \mathrm{Fe}_{6} \mathrm{C}$ carbide are marked as ' $\mathrm{x}$ '); radiation $\mathrm{Cu} K_{\alpha}$. 
5 hours in a ball mill (Fig. 2) are similar to each other and to that for $\mathrm{W}_{2} \mathrm{C}$ carbide (Fig. 1). That is why the trial model for $\mathrm{Mo}_{2} \mathrm{C}$ was taken in a frame of the most simple $\mathrm{W}_{2} \mathrm{C}$-type structure with $a=0.2991(5) \mathrm{nm}$, $c=0.4744(2) \mathrm{nm}: P-3 \mathrm{~m} 1$ space group, Mo in 2(d) 0.3330 .6670 .25 and $\mathrm{C}$ in 1(a) 000 . Although the refining of atomic position filling, texture and isotropic temperature factors, fulfilling within the framework of this structural model leads to a good agreement between experimental and calculated intensities of reflections in diffraction pattern (the reliability factors $R_{\mathrm{B}}$ is about 0.07 ) but the calculated value of Mo content is equal just to 58(1) at.\% Mo, which is not enough for the $\mathrm{Mo}_{2} \mathrm{C}$ phase formation as it was mentioned above for the case of $\mathrm{W}_{2} \mathrm{C}$. Therefore, the structural model of the $\zeta-\mathrm{Fe}_{2} \mathrm{~N}$-type structure was used as a trial model for $\mathrm{Mo}_{2} \mathrm{C}$ carbide obtained after 5 hours of treatment in a ball mill. It was shown that results of calculation listed in Table 2 define the crystal structure correctly. Although the fraction of vacancies in the metal sublattice $(\cong 38$ at. $\% \mathrm{C})$ is somewhat higher than that inherent to the carbon-rich side $(\cong 35$ at. $\% \mathrm{C}$ ) of solid solution based on the high temperature $\mathrm{Mo}_{2} \mathrm{C}$ carbide. It should be noted that good enough result was obtained in a case of calculation within the framework of the orthorhombic $\mathrm{Mo}_{2} \mathrm{C}$-type structure model. However, in our opinion, more symmetrical $\zeta-\mathrm{Fe}_{2} \mathrm{~N}$-type structure model is preferable.

$D$ and $\varepsilon$ meanings of the $\mathrm{Mo}_{2} \mathrm{C}$ carbides formed in the milled nanocomposite estimated by the Williamson-Hall plots are presented in Table 1 . It is shown that grain size values for $\mathrm{Mo}_{2} \mathrm{C}$ carbides synthesized by mechanical alloying are equal to $12 \mathrm{~nm}$.

Thus, the results obtained have revealed that $\mathrm{Mo}_{2} \mathrm{C}$ carbide with $\zeta$ $\mathrm{Fe}_{2} \mathrm{~N}$-type structure formed after 4 hours of mechanical alloying of the molybdenum powder and CNTs in a high-energy ball mill.

It should be noted that utilization of CNTs instead of activated carbon or graphite [5, 6] has some features. Authors of Ref. [14] have revealed the staged milling of the carbon nanotubes, in which CNTs are destroyed up to onion-like particles after $15 \mathrm{~min}$ of treatment in a high-energy ball mill and then turned into an amorphous carbon with further (up to $60 \mathrm{~min}$ ) processing. Therefore, one might assume that, at the first stage of mechanical alloying of the metal-CNTs charge, the two processes take place, namely, amorphization of CNTs and a crushing of metal particles.

The combined effect of these processes results in a penetration of the carbon atoms into the grain boundaries of metal particles at milling, which generally increases the contact area between the metal and carbon atoms. Consequently, the amorphous carbon particles actively interact with tungsten or molybdenum after 4 hours of processing in a ball mill already, forming the defect lattice of $\mathrm{Me}_{2} \mathrm{C}$ carbides. Moreover, the milling products obtained by mechanical alloying are nanocrystalline materials with the grain size of $4 \mathrm{~nm}$ for $\mathrm{W}_{2} \mathrm{C} / \mathrm{WC}$ carbides 
and of $12 \mathrm{~nm}$ for $\mathrm{Mo}_{2} \mathrm{C}$.

Unfortunately, the formation of the $\mathrm{WC}$ or $\mathrm{Mo}_{2} \mathrm{C}$ carbides in the test samples is accompanied by the wear debris leading to creation either the cubic $\mathrm{W}_{6} \mathrm{Fe}_{6} \mathrm{C}$ phase with $a=1.093(1) \mathrm{nm}$ or cubic $\mathrm{Mo}_{3} \mathrm{Fe}_{3} \mathrm{C}$ with $a=1.113(1) \mathrm{nm}$, the amount of which gradually increases with processing time increasing. Therefore, we are certain that, after this problem, the mechanical alloying of the CNT containing charge will give us a possibility to create novel nanoscale materials with a high potential in various engineering applications.

\section{CONCLUSIONS}

Providing experiments have revealed that 4 hours processing in a ball mill of mixture containing the tungsten/molybdenum powder with CNTs results in a formation of the high-temperature $\mathrm{W}_{2} \mathrm{C}$ and $\mathrm{Mo}_{2} \mathrm{C}$ carbides. These carbides are known to form congruently from the melt at normal conditions. XRD study reveals that the model preferred for description of the crystal structure of both carbides is the $\zeta-\mathrm{Fe}_{2} \mathrm{~N}$-type with vacancies in the metal sublattice. Further processing of $\mathrm{W}-\mathrm{CNTs}$ mixture (up to 10 hours) is accompanied by $\mathrm{W}_{2} \mathrm{C}+\mathrm{CNTs} \rightarrow \mathrm{WC}$ transformation resulting in existence of the equiatomic WC monocarbide in the milled nanocomposite. In our opinion, the substitution of the graphite by the carbon nanotubes is more advantageous for high temperature carbide manufacturing via mechanical alloying route since the use of CNTs significantly shortens the synthesis time.

\section{REFERENCES}

1. Transition Metal Carbides and Nitrides (Ed. L. E. Toth) (New York: Academic Press: 1971).

2. M. Sherif El-Eskandarany, Mechanical Alloying: Nanotechnology, Materials Science and Powder Metallurgy (Oxford: William Andrew: 2015).

3. C. Suryanarayana, Progr. Mater. Sci., 46, No. 1: 1 (2001).

4. C. Suryanarayana and N. Al-Aqeeli, Progr. Mater. Sci., 58: 383 (2013).

5. G. M. Wang, S. J. Campbell, A. Calka, and W. A. Kaczmarek, J. Materials Sci., 32, No. 6: 1461 (1997).

6. M. Sherif El-Eskandarany, A. A. Mahday, H. A. Ahmed, and A. H. Amer, J.Alloys Compd., 312, Nos. 1-2: 315 (2000).

7. O. Boshko, O. Nakonechna, N. Belyavina, M. Dashevskyi, and S. Revo, Adv. Powder Technol., 28, No. 3: 964 (2017).

8. V. K. Pecharsky and P. Y. Zavalij, Fundamentals of Powder Diffraction and Structural Characterization of Materials (New York: Springer: 2009).

9. M. Dashevskyi, O. Boshko, O. Nakonechna, and N. Belyavina, Metallofiz. Noveishie Tekhnol., 39, No. 4: 541 (2017) (in Ukrainian).

10. G. K. Williamson and W. H. Hall, Acta Metallurgica, 1, No. 1: 22 (1953).

11. H. Okamoto, J. Phase Equilibria and Diffusion, 29, No. 6: 543 (2008). 
12. Binary Alloy Phase Diagrams (Ed. T. B. Massalski) (Materials Park, Ohio: ASM International: 1990), vol. 1, p. 861.

13. N. P. Lyakishev, Fazovye Diagrammy Binarnykh Metallicheskikh Sistem [Phase Diagrams of Binary Metallic Systems] (Moscow: Mashinostroenie: 1996), vol. 1, p. 992 (in Russian).

14. Y. B. Li, B. Q. Wei, J. Liang, Q. Yu, and D. H. Wu, Carbon, 37: 493 (1999). 